\title{
Pengaruh Mikroba Pelarut Fosfat dan Pupuk P terhadap P Tersedia, Aktivitas Fosfatase, P Tanaman dan Hasil Padi Gogo (Oryza sativa. L.) pada Ultisol
}

\author{
Betty Natalie Fitriatin ${ }^{1}$, Anny Yuniarti ${ }^{1}$, Oviyanti Mulyani ${ }^{1}$, \\ Feni Siti Fauziah² dan Mohamad Dion Tiara ${ }^{2}$ \\ 1)Jurusan Ilmu Tanah Fakultas Pertanian Universitas Padjadjaran \\ 2)Alumni Jurusan Ilmu Tanah Fakultas Pertanian Universitas Padjadjaran \\ Jalan Raya Bandung Sumedang KM. 21 Jatinangor 40600 \\ Korespondensi: fitriatin@yahoo.com
}

\begin{abstract}
Effect of phosphate solubilizing microbe and phosphate fertilizer on available-P, phosphatase activity, plant $\mathrm{P}$ and upland rice (Oryza sativa L.) yield on Ultisols
\end{abstract}

Phosphate solubilizing microbe (PSM) is an essential microbes that carry out mobilization of soil phosphorous and hence facilitate its uptake by roots. The green house experiment was done to determine the effect of adding PSM and phosphorate (P) fertilizer on available-P, phosphatase activity, PSM population, plant $\mathrm{P}$ concentration and upland rice (Oryza sativa L.) yield grown on Ultisols. Experiment was set up in Factorial Randomized Block Design consisted of two factor, i.e. variety of PSM inoculant and phosphate fertilizer dosage. Results showed that there were no significant interaction effect between variety of PSM inoculant and phosphate fertilizer dosage on all parameter. However inoculation of mixed inoculant (Pseudomonas sp. dan Penicillium sp.) could enhance phosphatse activiy, shoot P up to $19,23 \%$ and husk dry weight up to $29,03 \%$. Application of $75 \mathrm{~kg} \mathrm{ha}^{-1} \mathrm{P}_{2} \mathrm{O}_{5}$ could increase available $\mathrm{P}$ in soil up to $20,66 \%$ and husk dry weight up to $15,23 \%$ compared with control.

Key words: Phosphate solubilizing microorganisms, Phosphatase, Phosphorous fertilizer, Ultisols.

\begin{abstract}
ABSTRAK
Mikroba pelarut fosfat (MPF) berperan penting dalam mobilisasi fosfor tanah dan selanjutnya memfasilitasi penyerapannya oleh akar tanaman. Penelitian rumah kaca telah dilakukan untuk mengetahui pengaruh mikroba pelarut fosfat dan pupuk $\mathrm{P}$ terhadap $\mathrm{P}$ tersedia, aktivitas fosfatase, populasi mikroba pelarut fosfat, dan konsentrasi $\mathrm{P}$ tanaman serta hasil tanaman padi gogo (Oryza sativa L.) yang ditanam pada Ultisols Jatinangor. Rancangan percobaan yang digunakan adalah Rancangan Acak Kelompok pola faktorial yang terdiri atas dua faktor yaitu jenis inokulan MPF dan dosis pupuk fosfat. Hasil penelitian menunjukkan bahwa tidak terdapat interaksi antara isolat mikroba pelarut fosfat dengan dosis pupuk P terhadap semua parameter penelitian. Namun inokulasi campuran Pseudomonas sp. dan Penicillium sp. mampu meningkatkan aktivitas fosfatase, konsentrasi $\mathrm{P}$ tajuk hingga 19,23 \% dan bobot gabah kering giling (GKG) padi gogo hingga 29,03\%. Aplikasi 75 kg $\mathrm{P}_{2} \mathrm{O}_{5} \mathrm{ha}^{-1}$ mampu meningkatkan $\mathrm{P}$ tersedia hingga 20,66 \% dan bobot GKG hingga 15,23\% dibandingkan kontrol.
\end{abstract}

Kata kunci: Mikroorganisme pelarut fosfat, Fosfatase, Pupuk fosfat, Ultisol. 


\section{PENDAHULUAN}

Di Indonesia, budidaya padi gogo dilakukan di lahan kering dengan tanah marjinal seperti Ultisol yang masam. Ketersediaan $\mathrm{P}$ di Ultisols rendah karena fiksasi $\mathrm{P}$ yang tinggi oleh mineral $\mathrm{Al}$ dan $\mathrm{Fe}$ (Hardjowigeno, 2003). Efektivitas pemupukan fosfat anorganik pada tanah Ultisol hanya $10 \%-30 \%$, sehingga $70 \%$ - $90 \%$ pupuk $\mathrm{P}$ tetap berada di dalam tanah dan tidak dapat diserap tanaman (Jones, 1982). Berdasarkan penelitian Barus (2005), pemupukan $100 \mathrm{~kg} \mathrm{P} \mathrm{ha-1} \mathrm{berpengaruh} \mathrm{terhadap} \mathrm{peningkatan}$ hasil panen dibandingkan dengan kontrol tetapi jika dosis pupuk ditingkatkan maka hasil panen akan menurun. Pada dosis $150 \mathrm{~kg} \mathrm{P} \mathrm{ha}^{-1}-200 \mathrm{~kg} \mathrm{P} \mathrm{ha}^{-1}$, hanya $5 \% \mathrm{P}-20 \% \mathrm{P}$ dapat diserap tanaman sehingga menimbulkan residu pupuk fosfat (Isgitani et al., 2005).

Efisiensi pemupukan yang rendah menyebabkan jumlah pupuk $\mathrm{P}$ yang diberikan oleh petani semakin meningkat sehingga berpotensi menurunkan produktivitas lahan khususnya pada tanah masam. Peningkatan efisiensi pemupukan $\mathrm{P}$ antara lain dapat dilakukan dengan inokulasi pupuk hayati mikroba pelarut fosfat (MPF). Mikroba ini dapat mengefisiensikan pupuk $\mathrm{P}$ anorganik melalui mekanisme produksi asam organik dan enzim fosfatase (Whitelaw, 2000). Asam organik membentuk khelat dengan kation $\mathrm{Al}$ dan Fe sehingga fosfat yang terikat $\mathrm{Al}$ dan Fe dilepaskan dan menjadi tersedia dan dapat diserap oleh tanaman (Rao, 1994).

Mikroba pelarut fosfat juga mampu mensekresikan enzim fosfatase yang berperan dalam proses hidrolisasi $\mathrm{P}$ organik manjadi $\mathrm{P}$ anorganik (George, et al., 2002; Vepsalainen \& Niemi, 2002; Saparatka, 2003; Zhongqi, et al. 2004). Bakteri pelarut fosfat (BPF) yang aktif di dalam tanah antara lain Bacillus, Pseudomonas, Arthrobacter, Micrococcus, Streptomyces, dan Flavobacterium (Whitelaw, 2000). Fungi Aspergillus sp. dan Penicillium sp.juga berperan aktif dalam melarutkan fosfat dalam tanah. Penicillium sp. melarutkan $26 \%$ hingga $40 \%$ $\mathrm{Ca}_{3}\left(\mathrm{PO}_{4}\right)_{2}$, sedangkan Aspergillus sp melarutkan 18 \% Ca3 $\left(\mathrm{PO}_{4}\right)_{2}$ (Chonkar \& Rao, 1967 dalam Elfiati, 2000).

Aktivitas MPF perlu dimanfaatkan untuk penyediaan fosfat bagi tanaman sehingga hasil tanaman dapat optimal. Inokulasi MPF eksogen diharapkan akan meningkatkan populasi dan aktivitasnya. Populasi MPF di tanah tergantung dari jenis tanah serta sesuai dengan keragaman tanaman yang dibudidayakan. Populasi MPF di rizosfer tanaman padi sekitar $10,08 \times 10^{5} \mathrm{CFU} \mathrm{g}^{-}$, serta dapat menyediakan P sebesar 29,41 $\mathrm{mg} \mathrm{kg}^{-1}$ untuk tanaman padi (Ponmurugan \& Gopi, 2006). Aktivitas dan kepadatan populasi mikroba tanah juga ditentukan oleh perubahan kondisi fisika dan kimia tanah (Spedding et al., 2004), jenis tanaman yang dibudidayakan, nutrisi tanah, $\mathrm{pH}$, kelembaban, bahan organik (Ponmurugan \& Gopi, 2006), serta teknik budidaya yang diterapkan (Mehrvarz et al., 2008).

Pada penelitian terdahulu telah diisolasi MPF, bakteri Pseudomonas sp. dan Bacillus subtilis serta fungi Aspergillus niger dan Penicillium sp., dari rizosfer tanaman pangan (Fitriatin et al., 2006) dan aktivitas fosfatase MPF tersebut telah dikarakterisasi secara biokimiawi (Fitriatin et al., 2007). Pada penelitin ini, akan diuji kemampuan MPF tersebut untuk mengurangi kebutuhan pupuk $\mathrm{P}$ tanaman padi gogo. Penelitian rumah kaca ini dilakukan untuk mengetahui pengaruh jenis inokulan MPF terhadap ketersediaan $\mathrm{P}$ tanah, kandungan fosfatase dan populasi MPF tanah serta kandungan $\mathrm{P}$ tanaman padi gogo yang ditanam di Ultisols dengan beberapa dosis pupuk fosfat.

\section{BAHAN DAN METODE}

Penelitian ini dilaksanakan di rumah kaca Fakultas Pertanian Universitas Padjadjaran, Jatinangor, Kabupaten Sumedang dengan ketinggian tempat $752 \mathrm{~m}$ dpl dan di laboratorium Biologi dan Bioteknologi Tanah Jurusan Ilmu Tanah Fakultas Pertanian Universitas Padjadjaran. Rancangan percobaan yang digunakan adalah Rancangan Acak Kelompok pola faktorial dengan tiga ulangan. Faktor pertama adalah jenis MPF yang terdiri atas tanpa MPF, Pseudomonas sp., Penicillium sp., dan campuran Pseudomonas sp. dan Penicillium sp. Faktor kedua yaitu dosis pupuk $\mathrm{P}$ yang terdiri atas tanpa pupuk P, $50 \%, 75 \%$ dan 100 $\%$ dosis pupuk $\mathrm{P}$ rekomendasi. Untuk padi gogo, dosis rekomendasi pemupukan $\mathrm{P}$ adalah $100 \mathrm{~kg} \mathrm{P}$ ha ${ }^{1}$ yang pada percobaan ini setara dengan $277,78 \mathrm{~kg}$ SP-36 ha-1 atau 1,38 g polibeg $^{-1}$.

Tanah yang digunakan adalah Ultisol asal Jatinangor ( $\mathrm{pH} 5,11, \mathrm{P}$ total sangat rendah 13,0 mg $100 \mathrm{~g}^{-1}$ dan $\mathrm{P}$ tersedia rendah $16,9 \mathrm{mg} 100 \mathrm{~g}^{-1}$ ) yang diambil dari kedalaman 0-20 cm. Pupuk kotoran sapi (50 g polibeg $\left.^{-1}\right)$ dicampurkan dengan tanah (10 kg per polibeg ${ }^{-1}$ ) dan diinkubasikan selama dua minggu. Aplikasi MPF dan pupuk P dilakukan pada saat tanam. MPF diberikan dengan kepadatan $10^{6}$ $\mathrm{CFU} \mathrm{ml} \mathrm{m}^{-1}$ sebanyak $10 \mathrm{ml}$ tanaman $^{-1}$. Benih padi gogo kultivar Situ Bagendit ditanam dengan cara tugal sebanyak lima benih di setiap polibeg. Setelah 
penjarangan pada 2 minggu setelah tanam, dibiarkan dua tanaman tumbuh selama percobaan.

Percobaan ini terdiri atas dua unit, yaitu satu unit untuk pengamatan pada vegetatif akhir yang meliputi $\mathrm{P}$ tersedia, kandungan fosfatase tanah, populasi MPFdi rizosfer dan konsentrasi $\mathrm{P}$ tanaman. Satu unit lainnya untuk pengamatan hasil pada fase generatif akhir yaitu bobot gabah kering giling dengan kadar air $12 \%-14 \%$. Data hasil pengamatan pada penelitian ini dianalisis dengan analisis ragam unvariate pada taraf $5 \%$. Apabila efek tersebut nyata, maka dilanjutkan dengan uji Jarak Berganda Duncan pada taraf $5 \%$.

\section{HASIL DAN PEMBAHASAN}

\section{Kandungan P Tersedia Tanah}

Hasil percobaan menunjukkan bahwa tidak terdapat interaksi antara isolat MPF dengan dosis pupuk $\mathrm{P}$ terhadap $\mathrm{P}$ tersedia. Namun demikian, aplikasi inokulasi campuran Pseudomonas sp. dan Penicillium sp. meningkatkan kandungan $\mathrm{P}$ tersedia tanah hingga 8,13 \% (Tabel 1). MPF mensekresikan asamasam organik yang dapat membentuk senyawa kompleks yang sukar larut. Terbentuknya senyawa kompleks ini akan menyebabkan fiksasi $\mathrm{P}$ menurun sehingga meningkatkan P-tersedia (Whitelaw, 2000).

Hasil percobaan juga menunjukkan bahwa pemberian $75 \mathrm{~kg} \mathrm{ha}^{-1} \mathrm{P}_{2} \mathrm{O}_{5}$ dapat meningkatkan $\mathrm{P}$ tersedia tanah sebesar 21,05\% pada fase vegetatif akhir, sedangkan pemberian $100 \mathrm{~kg} \mathrm{ha}^{-1} \mathrm{P}_{2} \mathrm{O}_{5}$ meningkatkan $\mathrm{P}$ tersedia tanah sebesar 20,66\%. Hasil ini sejalan dengan penelitian Fitriatin et al. (2008) menunjukkan bahwa pemberian pupuk $\mathrm{P}$ serta peningkatan dosis $\mathrm{P}$ hingga taraf optimum akan terus meningkatkan ketersediaan $\mathrm{P}$ dalam tanah.
Pemberian $75 \mathrm{~kg} \mathrm{ha}^{-1} \mathrm{P}_{2} \mathrm{O}_{5}$ juga lebih meningkatkan $\mathrm{P}$ tersedia daripada $100 \mathrm{~kg} \mathrm{ha}^{-1} \mathrm{P}_{2} \mathrm{O}_{5}$. Diduga, transfer $\mathrm{P}$ ke dalam larutan tanah masih rendah karena terfiksasi oleh mineral Fe. Dengan demikian, apabila dosis pemupukan meningkat maka akan meninggalkan residu pupuk $\mathrm{P}$ yang tidak dapat terserap secara optimal oleh tanaman.

MPF campuran Pseudomonas sp. dan Penicillium sp. merupakan inokulan yang lebih berpotensi meningkatkan ketersediaan $\mathrm{P}$ tanah dibandingkan dengan inokulan BPF tunggal. Fungi telah terbukti lebih mampu bertahan pada $\mathrm{pH}$ tanah yang rendah seperti Ultisols dibandingkan bakteri (Rao, 1994) sehingga aktivitasnya dalam melarutkan $P$ melalui produksi asam organik maupun fosfatase juga mungkin lebih baik.

\section{Fosfatase Tanah}

Aktivitas fosfatase tanah Ultisols dapat ditingkatkan dengan inokulasi MPF. Pada Tabel 2 terlihat bahwa perlakuan Pseudomonas sp. berkontribusi nyata meningkatkan aktivitas fosfatase sebesar 144,72\% dibandingkan dengan kontrol. Bahkan aplikasi Pseudomonas sp.bersamaan dengan Penicillium sp. meningkatkan aktivitas fosfatase yang lebih tinggi lagi, yaitu 150 \% dibandingkan dengan kontrol. Data tersebut memberikan pemahaman bahwa terjadi sinergisme antara Pseudomonas sp. dan Penicillium sp. dalam menghasilkan enzim fosfatase. Hal ini dimungkinkan karena sifat tanah Ultisols yang masam sehingga fungi pelarut fosfat lebih mempengaruhi aktivitas fosfatase. Kemasaman sangat mempengaruhi aktivitas fosfatase (Vepsalainen \& Niemi, 2002). Hasil penelitian Fitriatin et al. (2008) menunjukkan bahwa aktivitas fosfatase fungi lebih dominan aktivitas fosfatasenya pada $\mathrm{pH}$ masam.

Tabel 1 . Pengaruh Jenis MPF dan dosis pupuk P P terhadap P-tersedia

\begin{tabular}{|c|c|c|c|c|c|}
\hline \multirow[t]{2}{*}{ Jenis MPF } & \multicolumn{4}{|c|}{ Pupuk P (kg $\left.\mathrm{P}_{2} \mathrm{O}_{5} \mathrm{ha}^{-1}\right)$} & \multirow[t]{2}{*}{ Rata-rata } \\
\hline & 50 & & 75 & 100 & \\
\hline & & & $-\mathrm{mg} \mathrm{kg}$ & 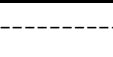 & . \\
\hline Tanpa MPF & 18,00 & 20,28 & 24,19 & 24,26 & 21,68 a \\
\hline Pseudomonas sp & 17,83 & 19,96 & 24,03 & 24,14 & 21,49 a \\
\hline Penicillium sp & 19,33 & 23,19 & 24,45 & 23,52 & $22,62 \mathrm{ab}$ \\
\hline Pseudomonas sp + Penicillium sp. & 21,78 & 22,75 & 24,81 & 25,08 & $23,61 \mathrm{~b}$ \\
\hline Rata-rata & $19,24 \mathrm{a}$ & $21,55 \mathrm{ab}$ & $24,37 \mathrm{~b}$ & $24,25 \mathrm{~b}$ & \\
\hline
\end{tabular}

Keterangan: Nilai rata-rata yang diikuti dengan huruf yang sama tidak berbeda nyata menurut Uji Jarak Berganda Duncan pada taraf $5 \%$. 
Tabel 2 . Pengaruh Jenis MPF dan dosis pupuk P terhadap fosfatase tanah

\begin{tabular}{lccccc}
\hline \multirow{2}{*}{ Jenis MPF } & \multicolumn{4}{c}{ Pupuk P $\left(\mathrm{kg} \mathrm{P}_{2} \mathrm{O}_{5} \mathrm{ha}^{-1}\right)$} & Rata-rata \\
\cline { 2 - 5 } & 0 & 50 & 75 & 100 & \\
\hline & & & & \\
Tanpa MPF & 51,95 & 86,92 & 74,49 & 109,04 & $80,60 \mathrm{a}$ \\
Pseudomonas sp & 37,68 & 230,99 & 240,61 & 279,73 & $197,25 \mathrm{~b}$ \\
Penicillium sp. & 100,72 & 189,53 & 182,64 & 132,47 & $151,34 \mathrm{ab}$ \\
Pseudomonas sp + Penicillium sp. & 282,03 & 227,72 & 224,04 & 72,19 & $201,50 \mathrm{~b}$ \\
\hline \multicolumn{1}{c}{ Rata-rata } & $118,09 \mathrm{a}$ & $183,79 \mathrm{~b}$ & $180,45 \mathrm{~b}$ & $148,36 \mathrm{ab}$ & \\
\hline
\end{tabular}

Keterangan: Nilai rata-rata yang diikuti dengan huruf yang sama tidak berbeda nyata menurut Uji Jarak Berganda Duncan pada taraf $5 \%$.

Tabel 3. Pengaruh Jenis MPF dan dosis pupuk $\mathrm{P}$ terhadap konsentrasi $\mathrm{P}$

\begin{tabular}{lccccc}
\hline \multirow{2}{*}{ Jenis MPF } & \multicolumn{3}{c}{ Pupuk P $\left(\mathrm{kg} \mathrm{P}_{2} \mathrm{O}_{5} \mathrm{ha}^{-1}\right)$} & Rata-rata \\
\cline { 2 - 5 } & 0 & 50 & 75 & 100 & $0,21 \mathrm{a}$ \\
\hline Tanpa MPF & 0,19 & 0,20 & 0,21 & 0,24 & $0,25 \mathrm{~b}$ \\
Pseudomonas sp & 0,24 & 0,24 & 0,25 & 0,28 & $0,26 \mathrm{c}$ \\
Penicillium sp. & 0,25 & 0,24 & 0,28 & 0,27 & $0,26 \mathrm{c}$ \\
Pseudomonas sp + Penicillium sp. & 0,25 & 0,25 & 0,26 & 0,27 & $0,26 \mathrm{c}$ \\
\hline \multicolumn{1}{c}{ Rata-rata } & $0,23 \mathrm{a}$ & $0,24 \mathrm{a}$ & $0,25 \mathrm{~b}$ & \\
\hline
\end{tabular}

Keterangan: Nilai rata-rata yang diikuti dengan huruf yang sama tidak berbeda nyata menurut Uji Jarak Berganda Duncan pada $5 \%$.

Pada percobaan ini, populasi MPF di rizosfer tidak dipengaruhi oleh inokulasi $\mathrm{MPF}$ maupun dosis pupuk P. Rata-rata populasi $\mathrm{MPF}$ adalah $1,65 \times 10^{6}-1,71 \times 10^{6}$ CFU g-1 yang tidak berbeda nyata untuk setiap perlakuan. Populasi tertinggi mikroba tanah adalah di rizosfer yang mengandung komponen karbon dan eksudat akar yang berlimpah sehingga dapat digunakan sebagai sumber energi untuk pertumbuhan mikroba tanah (Widawati \& Suliasih, 2006). Terlihat bahwa aktivitas fosfatase tidak berkaitan dengan populasi MPF. Aktivitas mikroba di dalam tanah bukan hanya ditentukan oleh ukuran populasi tetapi juga oleh faktor tanah lainnya yang saling berinteraksi (Rao, 1994).

\section{Konsentrasi P Tajuk Tanaman Padi Gogo}

Pemberian inokulan Pseudomonas sp, Penicillium sp, dan inokulan campuran (Pseudomonas sp. dan
Penicillium sp.) masing-masing meningkatkan $\mathrm{P}$ di tajuk secara signifikan (Tabel 3). Mikroba pelarut fosfat dapat mensubtitusi sebagian atau keseluruhan kebutuhan tanaman akan pupuk P. Bahkan menurut Prihatini et al. (1997), inokulan MPF memiliki potensi yang sama dengan pupuk TSP dalam menyediakan $\mathrm{P}$ untuk diserap tanaman.

Inokulasi Penicillium sp. dan campuran Pseudomonas sp. dan Penicillium sp. meningkatkan konsentrasi P tajuk sebesar 19,23 \%. Pseudomonas sp. hanya meningkatkan P tajuk sebesar $16 \%$. Fakta ini menjelaskan kembali bahwa aktivitas fungi lebih baik pada $\mathrm{pH}$ rendah jika dibandingkan dengan bakteri. Sifat mutualisme fungi dapat mengoptimalkan serapan $\mathrm{P}$ tanaman sehingga konsentrasi $\mathrm{P}$ tanaman meningkat (Mehrvarz et al., 2008). Fungi pelarut fosfat (FPF) dapat meningkatkan konsentrasi $\mathrm{P}$ terlarut sebesar $27 \%-47 \%$ di tanah masam (Lestari, 1994). Peningkatan konsentrasi P karena 
FPF lebih efektif melepaskan $\mathrm{P}$ terfiksasi dalam mineral tanah sehingga serapan $\mathrm{P}$ meningkat (ElAzouni, 2008).

Pemberian pupuk $\mathrm{P}$ setara $\mathrm{P}_{2} \mathrm{O}_{5} 75$ dan 100 $\mathrm{kg} \mathrm{ha}^{-1}$ meningkatkan $\mathrm{P}$ tajuk (Tabel 3). Tanaman memberikan respons optimal terhadap pemupukan sehingga pemberian pupuk $75 \%$ dan $100 \%$ dosis rekomendasi meningkatkan $\mathrm{P}$ tajuk masing-masing 8 $\%$ dan $11,54 \%$.
Fe, Bo, dan Mn sehingga unsur hara menjadi tidak seimbang dan akibatnya akan mengganggu aktivitas akar untuk menyerap unsur hara. Semakin tinggi kandungan har tanah yang dihasilkan dari pemupukan, maka respon tanaman semakin kecil terhadap pemupukan (Barus, 2005).

Tabel 4. Pengaruh jenis MPF dan dosis pupuk $\mathrm{P}$ terhadap bobot gabah kering giling

\begin{tabular}{|c|c|c|c|c|c|}
\hline \multirow[b]{2}{*}{ Jenis MPF } & \multicolumn{4}{|c|}{ Pupuk P (kg $\left.\mathrm{P}_{2} \mathrm{O}_{5} \mathrm{ha}^{-1}\right)$} & \multirow{2}{*}{$\begin{array}{c}\text { Rata-rata } \\
\left(\text { gr polibeg }^{-1}\right)\end{array}$} \\
\hline & 0 & 50 & 75 & 100 & \\
\hline & \multicolumn{5}{|c|}{ 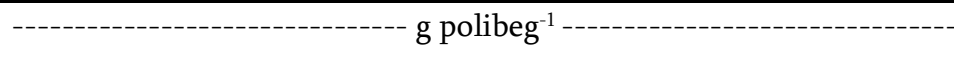 } \\
\hline Tanpa & 24,44 & 37,63 & 29,56 & 27,65 & 29,82 a \\
\hline Pseudomonas sp & 40,77 & 33,30 & 50,83 & 33,89 & $39,70 \mathrm{~b}$ \\
\hline Penicillium sp. & 46,02 & 31,97 & 44,74 & 21,69 & $36,11 \mathrm{ab}$ \\
\hline Pseudomonas sp + Penicillium sp. & 33,97 & 42,08 & 46,15 & 45,89 & $42,02 \mathrm{c}$ \\
\hline Rata-rata & $36,30 \mathrm{~b}$ & $36,25 \mathrm{~b}$ & $42,82 \mathrm{c}$ & $32,28 \mathrm{a}$ & \\
\hline
\end{tabular}

Keterangan: Nilai rata-rata yang diikuti dengan huruf yang sama tidak berbeda nyata menurut Uji Jarak Berganda Duncan pada taraf $5 \%$.

\section{Hasil Tanaman Padi Gogo}

Hasil percobaan menunjukkan bahwa tidak terdapat pengaruh interaksi yang nyata antara jenis MPF dengan pupuk $\mathrm{P}$ terhadap bobot gabah kering giling (GKG). Namun efek mandiri pemberian inokulan campuran Pseudomonas sp. dan Penicillium sp. mampu meningkatkan bobot GKG sebesar 29,03 \% (Tabel 4). Peningkatan ini sejalan dengan efek inokulasi campuran MPF terhadap peningkatan $\mathrm{P}$ tersedia tanah.

Bakteri Pseudomonas sp. dan fungi Penicillium sp. bekerja secara sinergis mengeluarkan enzim fosfatase dalam proses mineralisasi dan imobilisasi untuk mengubah $\mathrm{P}$ organik menjadi $\mathrm{P}$ anorganik. Kesinergisan tersebut membantu menyediakan $\mathrm{P}$ bagi tanaman padi gogo seingga pengisian bulir-bulir padi dapat meningkat.

Aplikasi pupuk $\mathrm{P}$ dengan dosis $75 \mathrm{~kg} \mathrm{ha}^{-1}$ $\mathrm{P}_{2} \mathrm{O}_{5}$ secara mandiri dapat meningkatkan hasil panen padi gogo sebesar 15,23 \%. Penambahan dosis pupuk $\mathrm{P}$ lebih dari $75 \mathrm{~kg} \mathrm{ha}^{-1} \mathrm{P}_{2} \mathrm{O}_{5}$ tidak meningkatkan hasil tanaman padi gogo, bahkan terjadi penurunan hasil tanaman sebesar 24,61\% pada aplikasi $100 \mathrm{~kg} \mathrm{P}_{2} \mathrm{O}_{5}$ $\mathrm{ha}^{-1}$. Pemupukan $\mathrm{P}$ dalam takaran yang tinggi akan menyebabkan kahatnya unsur hara mikro seperti Zn,

\section{SIMPULAN}

Hasil penelitian menunjukkan bahwa tidak terdapat pengaruh interaksi yang nyata antara isolat mikroba pelarut fosfat dengan dosis pupuk $\mathrm{P}$ terhadap $\mathrm{P}$ tersedia, aktivitas fosfatase, populasi mikroba pelarut fosfat, konsentrasi $\mathrm{P}$ tanaman, dan hasil panen padi gogo pada Ultisols Jatinangor. Namun inokulasi campuran Pseudomonas sp. dan Penicillium sp. mampu meningkatkan aktivitas fosfatase dan konsentrasi P tajuk hingga 19,23 \% dan bobot GKG padi gogo hingga 29,03 \%. Aplikasi 75 kg $\mathrm{P}_{2} \mathrm{O}_{5} \mathrm{ha}^{-1}$ mampu meningkatkan $\mathrm{P}$ tersedia hingga 20,66 \% dan bobot GKG hingga 15,23 \% dibandingkan kontrol.

\section{UCAPAN TERIMAKASIH}

Terima kasih kami kepada Ditjen Dikti Departemen Pendidikan Nasional yang telah mendanai penelitian ini melalui program Hibah Bersaing. Terima kasih juga kami sampaikan kepada staf di Laboratorium Biologi dan Bioteknologi Tanah Faperta Unpad serta staf di Laboratorium Penelitian dan Kimia Bahan Alam FMIPA Unpad. 


\section{DAFTAR PUSTAKA}

Barus, J. 2005. Respon tanaman padi terhadap pemupukan $\mathrm{P}$ pada tingkat status hara $\mathrm{P}$ tanah yang berbeda. Jurnal Akta Agrosia 8: 52-55.

El-Azouni, IM. 2008. Effect of phosphate solubilizing fungi on growth and nutrient uptake of soybean (Glycine max L.) plants. Journal of Applied Science Research. 4: 592-598.

Elfiati, D dan A Rauf. 2000. Uji pemanfaatan jamur pelarut fosfat untuk peningkatan efisiensi pemupukan $\mathrm{P}$ pada Aeric Haplaquox. Prosiding Kongres Nasional VII HITI, Bandung. Buku I. Hal. 645-654.

Fitriatin, BN, R Hindersah dan P.Suryatmana. 2006. Aktivitas Enzim Fosfatase dan Status Hara P Tanah Ultisols pada Pola Tumpangsari Tanaman Pangan dan Jati (Tectona grandis L.f.) yang dipengaruhi oleh Pupuk Hayati. Laporan Penelitian. Lembaga Penelitian Universitas Padjadjaran, Bandung.

Fitriatin, BN., B Joy dan T Subroto, 2007. Karakterisasi Aktivitas Fosfatase Mikroba Tanah dan Daya Katalisisnya terhadap Mineralisasi P Organik. Laporan Penelitian. Program Insentif Riset Dasar Kementerian Negara Riset dan Teknologi. Lembaga Penelitian Universitas Padjadjaran, Bandung.

Fitriatin, BN, B Joy, and T Subroto, 2008. The influence of organic phosphorous substrate on phosphatase activity of soil microbes. 2008. Paper presented on International Seminar of Chemistry. Bandung, 30-31 October, 2008.

George, TS, PJ Gregory, M Wood, D Read and RJ Buresh. 2002. Phosphatase activity and organic acids in the rhizosphere of potential agroforestry species and maize. Soil Biol. Biochem. 34: 1487-1494.

Hardjowigeno, S. 2003. Ilmu Tanah. Akademika Pressindo, Jakarta.

Isgitani, M, S Kabirun dan SA Siradz. 2005. Pengaruh inokulasi bakteri pelarut fosfat terhadap pertumbuhan shorghum pada berbagai kandungan $\mathrm{P}$ tanah. Jurnal Ilmu Tanah dan Lingkungan. 5: 48-54.

Jones, US. 1982. Fertilizer and Soil Fertility. Second edition. Reston Publ. Co. Reston, Virginia.
Lestari, P. 1994. Pengaruh fungi pelarut fosfat terhadap serapan hara $\mathrm{P}$ dan pertumbuhan tanaman jagung. Skripsi. Fakultas Pertanian Insistut Pertanian Bogor.

Mehrvarz, S, MR Chaichi and HA Alikhani. 2008. Effect of phosphate solubilizing microorganisms and phosphorus chemical fertilizer on yield and yield components of barely (Hordeum vulgare L.). AmericanEurasian J. Agric. \& Environ. Sci. 3: 822-828.

Ponmurugan, P and C Gopi. 2006. Distribution pattern and screening of phosphate solubilizing bacteria isolated from different food and forage crops. Journal of Agronomy. 5: 600-604.

Prihatini, T, S Komriah, A Hamzah dan E Suhaeti. 1997. Penambangan residu $\mathrm{P}$ secara biologis di lahan sawah. Prosiding Penelitian Tanah. Hal. 89-98.

Rao, S. 1994. Mikroorganisme Tanah dan Pertumbuhan Tanaman. Ed 2. UI-Press, Jakarta.

Saparatka, N. 2003. Phosphatase activities (ACP, ALP) in Agroecosystem Soils. Doctoral thesis. Swedish University of Agricultural Sciences. Uppsala.

Spedding, TA, C Hamel, GR Mehuys and CA Madramootoo. 2004. Soil microbial dynamics in maize-growing soil under different tillage and residue management systems. Soil Biol. Biochem. 36: 499-512.

Vepsalainen, M and RM Niemi. 2002. pH optima of enzyme activities in different soils. Poster presentation in Symposium no. $12.17^{\text {th }}$ WCSS, Thailand, 14-21 August 2002.

Widawati dan Suliasih. 2006. Populasi bakteri pelarut fosfat (BPF) di Cikaniki, Gunung Botol, dan Ciptarasa, serta kemampuannya melarutkan $\mathrm{p}$ terikat di media pikovskaya padat. Biodiversitas. 7: 109-113.

Whitelaw. 2000. Growth promotion of plants inoculated with phosphate solubilizing fungi. Adv. Agron. 69: 99-151.

Zhongqi He, SG Thimothy and H Wayne. 2004. Enzymatic hydrolisis of organic phosphorus in swine manure and soil. J. Environ. Qual. 33: 367-372. 